KALAMATIKA Jurnal Pendidikan Matematika

Volume 3, No. 1, April 2018, hal. 63-80

$\mathbf{K} \backslash \mathbf{L} \backslash \mathbf{M} / \mathbf{T} \mid \mathbf{K} \wedge$

\title{
BAHAN AJAR PADA MATERI GARIS SINGGUNG LINGKARAN DENGAN PENDEKATAN SAINTIFIK UNTUK SISWA SMP
}

\author{
Sowanto \\ Sekolah Tinggi Ilmu Pendidikan (STKIP) Bima \\ sowantos@gmail.com
}

\begin{abstract}
ABSTRAK
Penelitian ini dilatarbelakangi dengan belum adanya bahan ajar tentang materi garis singgung lingkaran yang mampu memfasilitasi siswa sekolah menengah pertama melalui pendekatan saintifik. Produk dari penelitian ini adalah menghasilkan bahan ajar yang dapat memfasilitasi siswa dalam bentuk lembar kerja siswa. Metode yang digunakan adalah penelitian desain (design research) yang meliputi: (1) desain permulaan (preliminary design), pada fase ini peneliti melakukan studi teori ditindaklanjuti dengan membuat hipotesis lintasan belajar atau Hypothetical Learning Trajectory (HLT); (2) eksperimen (experiment), pada fase ini desain yang sudah ada diujicobakan kepada siswa untuk menyelidiki proses belajar berkaitan dengan proses perkembangan cara berpikir siswa dalam situasi dan suasana belajar yang terbentuk dari HLT; (3) analisis tinjauan (retrospective analysis), pada fase ini peneliti membandingkan HLT dengan proses belajar siswa yang sesungguhnya. Adapun hasil dari uji coba menunjukkan bahwa bahan ajar yang dikembangkan dengan mempertimbangkan learning obstacle dan studi pendahuluan mampu memfasilitasi siswa sebagai sumber pendukung kegiatan pembelajaran.
\end{abstract}

Kata Kunci : bahan ajar, penelitian desain, garis singgung lingkaran.

\begin{abstract}
This research is motivated by the lack of teaching materials on tangent topic to the circle that is able to facilitate junior high school students through a scientific approach. This research produced teaching materials so-called students' worksheets that can facilitate students. The research used the design research which includes: (1) preliminary design, in this phase the researchers conducted a theory study which followed up by making a Hypothetical Learning Trajectory (HLT); (2) experiment, in this phase, the existing design is tested to the students to investigate the learning process that related to the process of developing students' thinking in situations and learning atmosphere that formed from HLT; (3) retrospective analysis, in this phase, the researchers compare the HLT with the actual student learning process. The results show that the teaching materials that have been developed by considering obstacle learning and preliminary studies are able to facilitate students as a source of support for learning activities.
\end{abstract}

Keywords: teaching materials, design research, tangent line to the circle.

Format Sitasi: Sowanto. (2017). Bahan Ajar pada Materi Garis Singgung Lingkaran dengan Pendekatan Saintifik untuk Siswa SMP. KALAMATIKA Jurnal Pendidikan Matematika, 3(1), 63-80. 
Penyerahan Naskah: 29 Agustus 2017 || Revisi: 30 Maret 2018 || Diterima: 31 Maret 2018

\section{PENDAHULUAN}

Struktur dan pengarahan yang kaku dalam belajar matematika akan membuat siswa memiliki kemampuan konseptualisasi yang terbatas, akibatnya siswa kesulitan ketika dihadapkan permasalahan yang baru karena konsep-konsep yang tidak dipahami secara utuh. Hal ini yang nantinya menjadi hambatan belajar (learning obstacle) bagi siswa. Lebih lanjut Mahyudi, Ariani, dan Ramadianti (2017) menyatakan bahwa pemilihan dan penggunaan sumber belajar yang tepat dalam suatu aktivitas dan proses pembelajaran berperan penting dalam mengarahkan pengalaman belajar bagi peserta didik. Untuk itu, guru hendaknya mengetahui dan memahami secara mendalam konsep matematika yang akan diajarkan dan sanggup menggambarkan pengetahuan secara fleksibel dalam tugas pembelajaran pada sumber belajar yang akan diberikan kepada siswa.

Guru yang merupakan salah satu sumber keilmuan memberikan cara pandang terhadap matematika dan akan berpengaruh terhadap cara menyampaikan matematika kepada siswa. Hal ini menjadikan bahwa berhasil tidaknya suatu proses kegiatan pembelajaran bergantung pada kemampuan kreativitas guru menciptakan proses belajar yang sedemikian rupa sehingga dapat merangsang siswa untuk belajar secara aktif (Slameto, 2010). Guru dituntut untuk mampu berinovasi menciptakan perangkat pembelajaran yang mampu menumbuhkembangkan kemampuan anak dalam pembelajaran matematika. Sesuai dengan yang dinyatakan Turmudi (2009) bahwa pembelajaran matematika sebagai salah satu bidang kelimuan yang tidak terlepas dari adanya guru, siswa, dan materi sebagai salah satu sumber bahan ajar.

Keberadaan bahan ajar akan sangat menunjang pencapaian hasil belajar yang baik pada setiap proses pembelajaran. Dalam menyusun bahan ajar, guru perlu memperhatikan pemahaman apa yang siswa tahu, kemudian membuat tantangan dan dorongan agar siswa belajar untuk memperoleh pengetahuan baru yang dituangkan dalam hipotesis lintasan belajar atau Hypothetical Learning Trajectory (HLT) yang memuat tentang antisipasi hal-hal yang mungkin akan terjadi serta proses berpikir siswa dalam proses pembelajaran matematika. Steffe dan D’Ambrosio (1995) mengungkapkan bahwa proses siswa mengkontruksi sendiri pemahamannya merupakan bagian terpenting dalam merancang pembelajaran. Dengan demikian, pengetahuan tidak ditransfer dari satu orang ke orang lain, tapi individu yang belajar membangun pengetahuan sendiri (Brousseau, 1997). Lebih lanjut Silver et al (1996) 
mengungkapkan bahwa dalam membangun pemahaman konsep pada pembelajaran matematika siswa harus diberikan kesempatan untuk menyelidiki dan merumuskan pertanyaan serta mampu menjelasakan masalah yang diajukan agar siswa memiliki pengalaman untuk mengenali dan memahami sendiri masalah dari konsep yang mereka pelajari.

Salah satu konsep matematika yang dipelajari mulai dari tingkat Sekolah Dasar (SD atau sederajat) sampai tingkat Sekolah Menengah Atas (SMA atau sederajat), bahkan sampai di perguruan tinggipun dipelajari secara lebih mendalam bagi mahasiswa yang mengambil bidang keahlian matematika, serta dipelajari secara terintegrasi dan kontinu adalah konsep lingkaran. Konsep lingkaran bila dikaitkan dengan bahan ajar, terdapat penelitian dari Malalina dan Kesumawati (2013) tentang pengembangan bahan ajar pada materi lingkaran yang menunjukkan bahwa pengembangan bahan ajar pada materi lingkaran mampu memfasilitasi siswa meningkatkan prestasi dan aktivitas belajar matematika siswa tentang materi lingkaran. Lebih lanjut materi lingkaran bila ditinjau dari segi struktur materi, konsep, dan prinsip-prinsipnya, pada dasarnya telah akrab dikenal oleh siswa dalam kehidupan seharihari. Siswa telah memililki pengetahuan awal atau prakonsep berdasarkan pengalaman yang telah diperolehnya tentang lingkaran, walaupun kenyataannya dalam proses pembelajaran materi lingkaran termasuk salah satu materi yang dianggap sulit oleh sebagian besar siswa.

Berdasarkan hasil observasi mengenai konsep lingkaran yang dilakukan responden pada salah satu SMP kelas VIII di kabupaten Bandung Barat, diperoleh beberapa hambatan belajar (learning obstacle) yang dialami oleh responden khususnya siswa SMP ketika mengerjakan soal mengenai materi garis singgung lingkaran. Learning obstacle yang pertama, berkaitan dengan materi garis singgung lingkaran dimana siswa masih mengalami kesalahan dalam memecahkan masalah yang terkait dengan konsep tersebut. Hambatan belajar ini diungkapkan juga oleh Yunus, Suyitno, dan Wahyudin (2013) bahwa siswa seringkali mengalami kesulitan dalam mempelajari materi geometri terlebih khusus garis singgung lingkaran. Dari hasil wawancara diperoleh bahwa letak kesalahan siswa adalah mereka masih mengalami kesulitan dalam memahami bahwa garis singgung lingkaran selalu tegak lurus dengan bidang singgungnya.

Hambatan belajar (learning obstacle) yang kedua, dari hasil uji coba instrumen yang telah dilakukan diperoleh bahwa siswa mengalami kesulitan dalam mempelajari konsep garis singgung lingkaran. Hal ini disebabkan karena siswa masih kesulitan dalam memilih dan 
menggunakan informasi mengenai materi prasyarat seperti konsep sudut maupun konsep phytagoras untuk menyelesaikan soal yang terkait dengan konsep garis singgung lingkaran. Learning obstacle yang ketiga, berdasarkan hasil dokumentasi dan wawancara dengan guru matematika kelas VIII, diperoleh bahan ajar yang dibuat adalah sangat rutin, dan memakai format yang sama dalam langkah pembelajarannya untuk setiap sub materi yang akan diajarkan. Begitu juga dengan LKS yang diberikan, cenderung hanya merupakan kumpulan soal-soal dan latihan rutin tanpa banyak siswa dilibatkan dalam menemukan konsep yang dipelajari. Hambatan belajar ini diperkuat oleh temuan Sholikhah, Budiyono, dan Saputro (2014) yang menyatakan bahwa salah satu penduga kesulitan siswa dalam menguasai materi adalah cara guru dalam menyampaikan materi ajar.

Berdasarkan paparan di atas, jika disesuaikan dengan hambatan belajar (learning obstacle) yang hadapi oleh siswa, maka perlu diadakan penelitian tentang "Pengembangan Bahan Ajar pada Materi Garis Singgung Lingkaran dengan Pendekatan Saintifik untuk Siswa SMP”.

\section{METODE PENELITIAN}

Metode penelitian yang digunakan pada penelitian ini adalah penelitian desain (design research). Menurut Lidinillah (t.t.), penelitian desain adalah sebuah penelitian yang menempatkan proses desain (perancangan) sebagai strategi untuk mengembangkan suatu bahan ajar. Lebih lanjut menurut Cobb et al (Mulyana, 2012) penelitian desain terdiri dari tiga fase yang saling membentuk proses siklik baik dalam setiap fase maupun dalam keseluruhan proses design research. Ketiga fase itu yaitu desain permulaan (preliminary design), eksperimen (experiment), dan analisis tinjauan (retrospective analysis). Penjelasan dari ketiga fase tersebut yaitu:

\section{Desain Permulaan (Preliminary First Design)}

Munculnya suatu masalah merupakan awal dari proses sebuah penelitian, penelitian desain pada fase pertama merupakan tahapan dimana peneliti melakukan suatu studi teori agar dapat memahami masalah lebih menyeluruh, dapat merumuskan pertanyaan penelitian, serta dapat mengajukan solusi yang tepat dalam menyelesaikan masalah tersebut. Hal ini ditindaklanjuti dengan dibuat hipotesis lintasan belajar atau Hypothetical Learning Trajectory (HLT). Dalam hal ini, HLT memuat tentang antisipasi hal-hal yang mungkin akan terjadi, 
termasuk proses berpikir siswa dalam proses pembelajaran. Hal-hal yang perlu dilakukan dalam membuat HLT adalah telaah literatur yang relevan, diskusi dengan guru yang sudah berpengalaman atau diskusi dengan pakar materi pembelajaran.

\section{Eksperimen (Experiment)}

Pada fase ini, desain yang sudah dirancang kemudian diujicobakan kepada siswa. Eksperimen pembelajaran pada penelitian desain bertujuan untuk menyelidiki proses belajar berkaitan dengan proses perkembangan cara berfikir siswa dalam situasi dan suasana belajar yang terbentuk dari HLT, sehingga akan terlihat kesesuaian antara hal-hal yang sudah diantisipasi dalam fase desain permulaan dengan kenyataan yang terjadi. Oleh karena itu, data penelitian dikumpulkan pada fase eksperimen ini.

\section{Analisis Tinjauan (Retrospective Analysis)}

Pada fase analisis tinjauan, peneliti membandingkan HLT dengan proses belajar siswa yang sebenarnya terjadi, kemudian melakukan analisis mengenai beberapa kemungkinan penyebabnya serta melakukan sintesis kemungkinan yang dapat dilakukan untuk memperbaiki HLT yang akan digunakan pada siklus berikutnya mengenai desain permulaan, eksperimen, dan analisis tinjauan selanjutnya. Setelah diperoleh bahan ajar yang baik melalui tiga fase tersebut, hasilnya dijadikan bahan untuk menyusun bahan ajar dalam materi lain.

\section{Subjek dan Data Penelitian}

Subjek penelitian ini terdiri dari subjek yang dijadikan tempat observasi kesulitan belajar siswa dan subjek yang dijadikan tempat ujicoba dari bahan ajar yang telah dikembangkan. Subjek yang dijadikan tempat observasi kesulitan belajar adalah satu kelas VIII di salah satu Sekolah Menengah Pertama (SMP) di kabupaten Bandung Barat pada semester 2 dengan kategori kemampuan rendah, sedang dan tinggi berdasarkan informasi dari guru matematika kelas VII.

Dalam penelitian ini digunakan teknik pengumpulan data berupa observasi dan wawancara. Observasi adalah suatu teknik evaluasi nontes yang menginventarisasikan data tentang sikap dan kepribadian siswa dalam kegiatan belajarnya (Suherman, 1990). Lebih lanjut dipaparkan oleh Arikunto (2010), observasi merupakan kegiatan yang meliputi pemusatan perhatian terhadap suatu objek dengan menggunakan seluruh alat indera yaitu penglihatan, pendengaran, penciuman, peraba, dan pengecap. Observasi ini dilakukan kepada 
siswa ketika pembelajaran sedang berlangsung dengan tujuan untuk mengetahui tugas-tugas dalam bahan ajar yang sulit diselesaikan siswa dan membutuhkan intervensi (bantuan) dari guru dalam penyelesaiannya.

Wawancara adalah percakapan dengan maksud tertentu, percakapan itu dilakukan oleh dua pihak yaitu pewawancara (interviewer) yang mengajukan pertanyaan dan yang diwawancarai (interviewe) yang memberikan jawaban atas pertanyaan itu (Moleong, 2010). Tujuan dari dilakukannya wawancara terhadap responden adalah untuk menggali informasi lebih mendalam dan merperjelas jawaban pertanyaan yang belum bisa merepresentasikan kesulitan siswa. Melalui wawancara peneliti dapat: (1) mengidentifikasi kesulitan siswa dalam menyelesaikan masalah matematis garis singgung lingkaran; (2) mengetahui tanggapan siswa terhadap bahan ajar yang dikembangkan dalam mengajar konsep garis singgung lingkaran, sehingga akan diketahui tugas-tugas mana yang dirasa sulit oleh siswa selain dari jawaban tugas-tugas pada bahan ajar yang dikerjakan siswa.

Data yang terkumpul berupa transkrip wawancara siswa, wawancara guru, hasil pekerjaan siswa pada tes kemampuan awal, dan jawaban siswa pada bahan ajar. Pengolahan data dilakukan sejak fase pertama sampai fase ketiga. Pada fase pertama diperoleh data mengenai hasil tes kemampuan awal siswa pada materi garis singgung lingkaran. Hasilnya kemudian dianalisis dengan memaparkan kesulitan yang dialami dalam mengerjakan permasalahan yang diberikan. Kemudian dibuat antisipasi untuk mengatasi kesulitan tersebut berupa HLT yang terdiri dari perencanaan pembelajaran dan tugas-tugas yang tersusun dalam suatu bahan ajar.

Miles dan Huberman dalam Sugiyono (2010) mengemukakan bahwa "aktifitas dalam analisis data kualitatif dilakukan secara interaktif dan dilakukan secara terus menerus sampai tuntas, sehingga datanya sudah jenuh". Setelah bahan ajar diselesaikan oleh siswa, maka dilakukan analisis terhadap jawaban-jawaban siswa sebagai suatu data. Teknik yang digunakan untuk menganalisis data tersebut berdasarkan Miles and Huberman (1984), yang menyatakan bahwa reduksi data (data reduction), penyajian data (data display), dan penarikan kesimpulan/verifikasi (conclusion drawing/verification) merupakan tiga aktivitas dalam analisis data kualitatif.

Reduksi data dimaksudkan untuk mempermudah pemahaman terhadap data yang telah terkumpul dengan cara merangkum dan mengklasifikasikan sesuai dengan masalah pada 
konsep garis singgung lingkaran. Kemudian dilakukan reduksi data dan dilanjutkan dengan penyajian data. Aktivitas terakhir yaitu melakukan penarikan kesimpulan berdasarkan data yang telah diperoleh untuk menjawab rumusan masalah.

\section{HASIL DAN PEMBAHASAN}

Penelitian desain merupakan sebuah penelitian yang mengembangkan bahan ajar dengan menempatkan proses desain (perancangan) sebagai strategi yang dilakukan. Dalam pelaksanaannya, penelitian ini dilakukan dengan tiga fase utama. Ketiga fase itu yaitu desain permulaan (preliminary design), eksperimen (experiment), dan analisis tinjauan (retrospective analysis).

\section{Desain Permulaan (Preliminary First Design)}

Pada fase ini, peneliti melakukan suatu studi teori agar dapat memahami masalah lebih menyeluruh, dapat merumuskan pertanyaan penelitian, serta dapat mengajukan solusi yang tepat dalam menyelesaikan masalah tersebut. Hal yang dilakukan setelah dilakukan studi pendahuluan adalah menganalisis kesulitan belajar siswa dan membuat HLT dari hasil wawancara dengan siswa dan guru.

Deskripsi hasil wawancara dengan siswa

Pada saat studi pendahuluan, dilakukan wawancara terhadap siswa yang telah melaksanakan uji coba awal instrumen dengan tujuan untuk mengetahui sumber belajar yang dimiliki dan kesulitan maupun hambatan yang dihadapi siswa pada proses pembelajaran matematika. Berdasarkan hasil wawancara diperoleh hasil bahwa dalam pelaksanaan pembelajaran matematika di kelas, siswa hanya terpaku dengan catatan dan buku paket yang berisi latihan-latihan rutin yang diberikan guru. Hal ini dapat dilihat dari jawaban siswa atas pertanyaan pewawancara pada potongan transkrip pada gambar 1 di bawah ini.

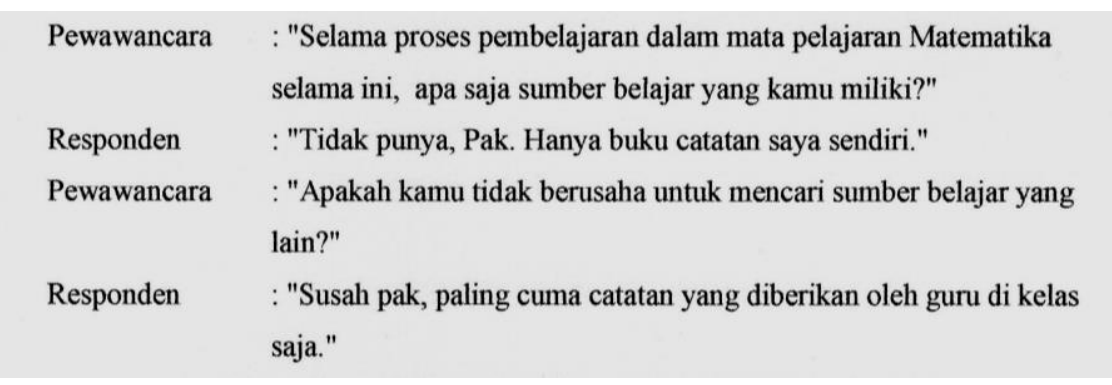

Gambar 1. Potongan transkrip hasil wawancara dengan siswa 
Dari potongan transkrip hasil wawancara dengan siswa pada gambar 1, dapat diketahui juga bahwa siswa tidak berusaha untuk mencari atau memiliki sumber belajar lain sehingga menjadikan guru sebagai tumpuan utama untuk mendapatkan penjelasan dari materi-materi yang tidak dipahami pada buku paketnya. Lebih lanjut, siswa menuturkan bahwa mereka mengalami kesulitan dalam memilih dan menggunakan informasi yang ada untuk menyelesaikan soal yang terkait dengan konsep garis singgung lingkaran. Setelah kembali dilakukan wawancara dengan siswa diperoleh informasi bahwa hal ini disebabkan karena siswa terpaku pada beberapa istilah yang disampaikan guru, tanpa memahami konsep dasar yang harus menjadi acauan siswa untuk menyelesaikan permasalahan tersebut. Siswa kesulitan juga menghubungkan pengetahuan yang dimiliki sebelumnya dengan permasalahan yang diberikan ketika uji coba instrumen karena siswa terbiasa hanya menghafal rumus-rumus yang berkaitan materi yang diberikan.

\section{Deskripsi hasil wawancara guru}

Dokumentasi dan wawancara dengan guru matematika kelas VIII bertujuan mengetahui cara mengajar guru dan kesulitan yang dialami siswa dalam mempelajari materi garis singgung lingkaran. Dari hasil dokumentasi diperoleh bahwa bahan ajar yang dibuat adalah sangat rutin dan setiap sub materi yang akan diajarkan memakai format yang sama dalam langkah pembelajarannya. Begitu juga dengan LKS yang diberikan, cenderung hanya merupakan kumpulan soal-soal dan latihan rutin. Dengan kata lain, learning trajectory yang merupakan rangkaian kegiatan yang disiapkan seorang guru untuk menyampaikan suatu konsep materi kepada siswa yang disesuaikan dengan tingkat kemampuan siswa dan urutan materi pembelajaran agar tercapai pembelajaran yang optimal, belum sepenuhnya dilakukan oleh guru.

Berdasarkan hasil wawancara yang dilakukan dengan guru diperoleh informasi bahwa guru telah mencoba menerapkan pembelajaran dengan pendekatan kontekstual melalui model kooperatif yang dilakukan dengan metode tanya jawab maupun diskusi. Hambatan yang dialami guru adalah siswa kesulitan saat mengerjakan materi tentang garis singgung lingkaran karena siswa masih kurang mampu melihat hubungan konsep dasar dari materi sebelumnya yang mendukung pemahaman dalam pembelajaran tentang garis singgung lingkaran seperti konsep sudut dan teorema phytagoras. 
Jawaban di atas adalah contoh dari kebanyakan jawaban yang di sampaikan oleh siswa. Siswa masih memahami bahwa garis singgung merupakan garis yang memotong bagian dalam lingkaran. Lebih lanjut ditemukan pula contoh jawaban siswa seperti di bawah ini, dimana siswa masih memahami bahwa garis singgung merupakan garis yang saling berhubungan satu ke titik satu lagi dalam lingkaran.

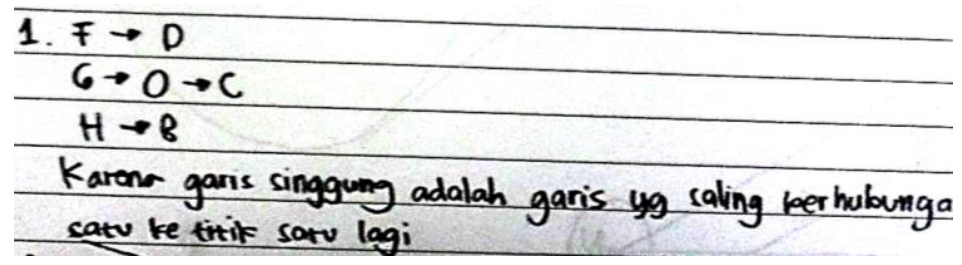

Gambar 4. Jawaban kedua dari siswa yang masih keliru

Berdasarkan beberapa jawaban di atas, dapat dilihat bahwa siswa tidak bisa menyelesaikan masalah yang terdapat pada item salah satu soal dalam penelitian ini sebagaimana semestinya. Ketika dilakukan wawancara, siswa menuturkan bahwa mereka mengalami kesulitan dalam mengerjakan soal tersebut karena mereka belum memahami kejelasan definisi garis singgung, sehingga ketika dihadapkan soal dengan beberapa garis yang terdapat pada lingkaran mengalami kesulitan dalam menentukannya.

\section{Hypothetical Learning Trajektori (HLT)}

HLT disusun sebagai tindak lanjut dari hasil analisis learning obstacle yang ditemukan dengan tujuan sebagai rangkaian perencanaan pembelajaran berdasarkan antisipasi atas kemungkinan pola pikir siswa dalam belajar untuk mengembangkan tujuan pembelajaran, membawakan materi berdasarkan pemahaman dan pengetahuannya tentang bagaimana siswa dapat memahami konsep, perkiraan tentang pengetahuan awal siswa, pemilihan tugas yang mampu membuat siswa untuk memiliki kenginan untuk memahami konsep.

Menurut Simon (2014), HLT terdiri dari tiga komponen yaitu tujuan pembelajaran, aktivitas pembelajaran, dan hipotesis pembelajaran yang akan terjadi. Berdasarkan hasil wawancara dengan siswa dan guru matematika kelas VIII serta analisis jawaban siswa, maka disusunlah HLT. Berikut adalah penjelasan mengenai salah satu hipotesis lintasan belajar siswa dalam kegiatan pembelajaran materi garis singgung lingkaran.

1. Tujuan Pembelajaran

Diberikan beberapa contoh dan non-contoh berupa gambar lingkaran yang dipotong tegak lurus oleh beberapa garis, siswa dapat mendefinisikan garis singgung lingkaran melalui 
kegiatan mengamati, menanya, mengeksplorasi, menalar, dan mengkomunikasikan berdasarkan pada karakteristik contoh yang diberikan.

2. Rencana aktifitas Pembelajaran

Rencana aktivitas pembelajaran dapat disusun dengan memperhatikan learning obstacle dan kajian teori yang berkaitan dengan pembelajaran. Pertama yaitu guru menyampaikan apersepsi tentang garis sejajar dengan tujuan untuk mengingatkan kembali kepada siswa tentang konsep yang berhubungan dengan konsep garis singgung lingkaran. Selanjutnya dalam kegiatan inti pembelajaran, guru menampilkan contoh-contoh benda dalam kegiatan sehari-hari yang berkaitan dengan garis singgung lingkaran. Hal ini dimaksudkan agar siswa merasa pembelajaran yang dilaksanakan berhubungan dengan kehidupan nyata dan bisa diaplikasikan dalam kehidupan sehari-hari.

Melalui contoh dan non-contoh yang diberikan siswa diharapkan mampu memberikan definisi sendiri berkaitan dengan garis singgung lingkaran yang didasarkan pada teori Vigotsky bahwa proses pembelajaran harus diawali dari masalah serta teori Bruner tentang teorema kekontrasan yaitu konsep dalam matematika akan lebih mudah dipahami apabila dikontraskan dengan konsep-konsep lain. Dalam LKS yang dibuat pada tugas bagian 1 ini, siswa dituntut untuk menentukan dari beberapa gambar yang diberikan yang mana yang merupakan garis singgung lingkaran.

\section{Tugas1}

Gambar di bawah ini merupakan gambar beberapa lingkaran yang diameternya dipotong tegak lurus oleh beberapa garis.

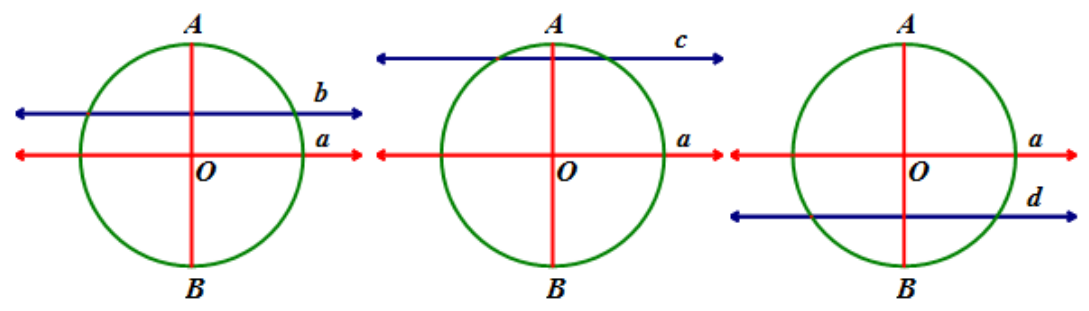

(i)

(ii)

(iii)

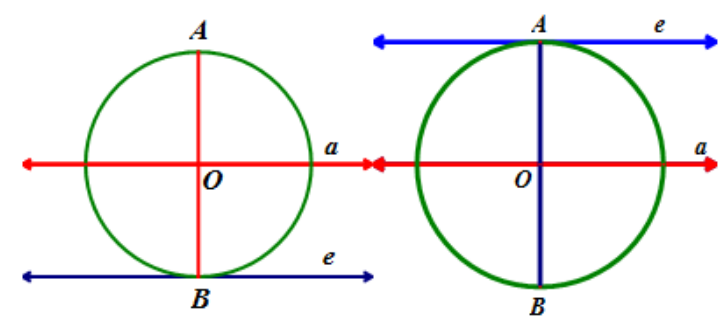

(iv)

(v) 
a. Coba kamu kelompokkan gambar yang garisnya sejajar garis a dan memotong lingkaran di dua titik! Sebutkan yang mana saja?

b. Adakah gambar yang garisnya sejajar dengan garis $a$ dan memotong lingkaran tepat di satu titik? Jika ada, coba kamu sebutkan!

c. Coba kalian sebutkan apa kesamaan dari dua kelompok gambar yang kalian buat dan sebutkan pula apa yang membedakannya?

d. Dari dua kelompok utama gambar yang telah kamu buat, yang manakah yang termaksud dalam gambar yang memiliki garis singgung? Jelaskan!

\section{Berdasarkan Tugas 1,}

Tulislah kesimpulan yang kalian dapat!

Garis singgung lingkaran adalah

西

Dapatkah kamu mencari benda-benda di sekitarmu yang dapat digunakan sebagai contoh garis menyinggung lingkaran? Sebutkan!

\section{Perkiraan pemikiran siswa (Hipothesis Thinking)}

Pada kegiatan pembelajaran tentang mendefinisikan garis singgung lingkaran, siswa kemungkinan akan kesulitan menentukan yang mana dari gambar-gambar yang telah dikelompokkan yang termaksud dalam kelompok gambar yang memiliki garis singgung.

4. Antisipasi solusi dari kesulitan siswa (Teacher Support) 
Beberapa hal yang dilakukan oleh guru ketika menemukan masalah seperti pada kasus di atas adalah dengan memberikan scaffolding kepada siswa dengan mengajukan pertanyaan yang membantu siswa antara lain:

a. Menanyakan kepada siswa tentang benda-benda yang bersinggungan. Misalnya Pernahkah kalian melihat rantai sepeda dan girnya, atau katrol dan talinya yang digunakan untuk menimba air?

b. Bagaimanakah rantai dengan girnya, apakah saling berpotongan? atau tali dan katrol untuk menimba air, apakah saling berpotongan?

c. Menurut pengamatan kalian itu termaksud contoh garis singgung atau bukan?

\section{Eksperimen (Experiment)}

Setelah melakukan penyusunan bahan ajar pada materi garis singgung lingkaran dengan pendekatan saintifik untuk siswa SMP, selanjutnya adalah mengujicobakannya pada beberapa orang siswa yang memiliki kategori kemampuan rendah, sedang dan tinggi berdasarkan informasi dari guru matematika kelas VIII di salah satu SMP di kabupaten Bandung Barat.

\section{Analisis Tinjauan (Retrospective Analysis)}

Pada tahap ini, hasil ujicoba yang dilakukan pada tahap eksperimen dilakukan analisis tinjauan. Berikut ini akan diuraikan analisis tinjauan dari masing-masing pembelajaran.

Analisis Tinjauan Terhadap Pembelajaran Mengenai Menemukan Definisi Garis Singgung Lingkaran

Pembelajaran dimulai dengan penyampaian apersepsi tentang garis sejajar yang bertujuan untuk mengingatkan kembali siswa tentang konsep garis yang sejajar dan sudut yang dibentuk oleh dua garis sejajar melalui tanya jawab. Setelah peneliti mengonfirmasi pemahaman siswa tentang konsep garis yang sejajar dan sudut yang dibentuk oleh dua garis sejajar, selanjutnya peneliti membagi kelas menjadi 2 kelompok yang terdiri dari 3 orang tiap kelompoknya, kemudian meminta siswa mengerjakan bahan ajar mengenai menemukan definisi garis singgung lingkaran yang dibagikan kepada masing-masing kelompok.

Pada bahan ajar tugas 1, siswa diberikan contoh dan non-contoh garis singgung lingkaran dan pertanyaan-pertanyaan yang mengarahkan siswa untuk mampu memberikan 
definisi garis singgung lingkaran sendiri. Terlihat bahwa pada awalnya beberapa siswa merasa bingung saat mengerjakan tugas 1.a. Siswa masih melihat bahwa semua contoh yang diberikan adalah memotong lingkaran di dua titik. Namun setelah diberi petunjuk dan diarahkan untuk coba memahami lagi soal yang diberikan, siswa tidak mengalami kesulitan untuk menyelesaikan tugas ini. Di bawah ini merupakan contoh jawaban siswa.

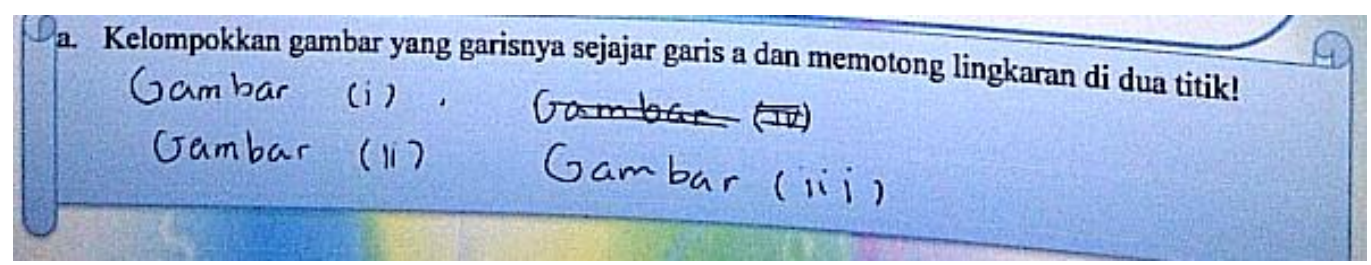

Gambar 5. Contoh jawaban tugas 1.a

Berdasarkan jawaban di atas, terlihat bahwa siswa sudah mampu untuk mengelompokkan gambar yang garisnya sejajar garis $a$ dan memotong lingkaran di dua titik. Selanjutnya tidak jauh berbeda dengan tugas 1.a, pada tugas 1.b siswa tidak mengalami kesulitan saat menyelesaikannya dan semua kelompok dapat menjawab dengan jawaban yang diharapkan. berikut ini contoh dari jawaban siswa.

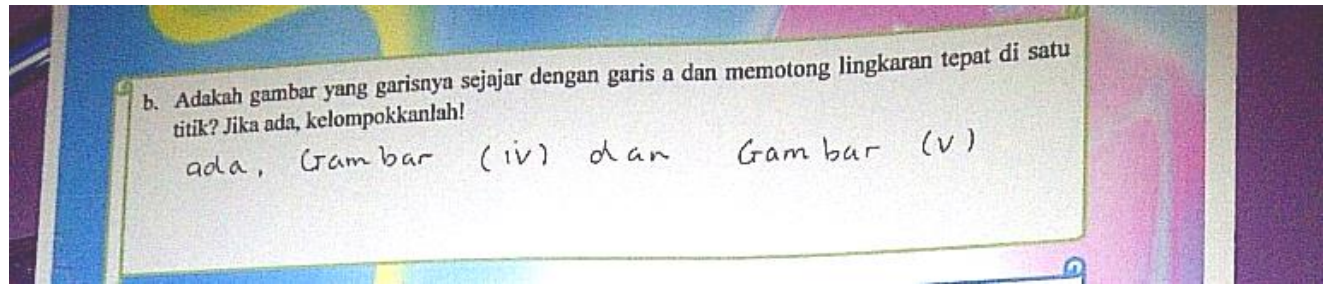

Gambar 6. Contoh jawaban tugas 1.b

Berdasarkan jawaban di atas, untuk tugas 1.b terlihat bahwa siswa sudah mampu untuk melihat dan mengelompokkan gambar yang garisnya sejajar dengan garis $a$ dan memotong lingkaran tepat di satu titik. Berdasarkan tugas 1.a dan 1.b siswa terlihat sudah mampu membedakan gambar yang garisnya sejajar garis $a$ dan memotong lingkaran di dua titik secara tegak lurus melalui diameter lingkaran.

Untuk tugas 1.c, melatih siswa untuk mengkonstruksi sendiri pemahamannya berdasarkan contoh dan noncontoh yang diberikan lingkaran yang memiliki garis singgung. Pada tugas 1.c ini siswa terlihat masih belum dapat menentukan yang mana dari gambar yang telah dikelompokkan yang memiliki garis singgung. Setelah diberi petunjuk, dan melalui tanya jawab dengan menanyakan tentang benda-benda yang berhubungan dengan garis singgung 
lingkaran siswa tidak mengalami kesulitan untuk menyelesaikan tugas ini. Di bawah ini merupakan contoh jawaban siswa.

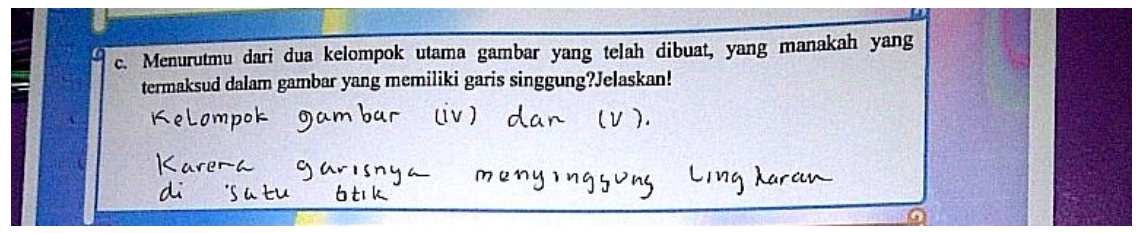

Gambar 7. Contoh jawaban tugas 1.c

Untuk tugas 1.d, setelah dari tugas 1.a sampai dengan tugas 1.c siswa dilatih untuk membedakkan yang mana yang merupakan gambar lingkaran yang dipotong oleh salah satu garis di satu titik dan tegak lurus dengan diameternya, maka pada tugas 1.d siswa dilatih untuk mengkonstruksi dengan bahasa sendiri apa yang merupakan definisi dari garis singgung lingkaran. Di bawah ini merupakan contoh jawaban siswa.

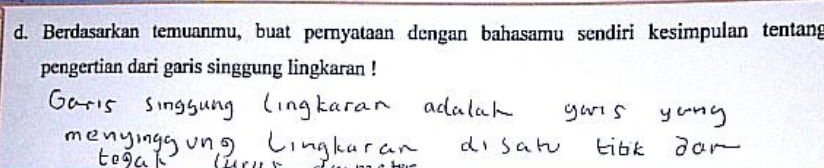

Gambar 8. Contoh jawaban tugas 1.d

Setelah menyelesaikan tugas 1 , siswa kemudian menyimpulkan secara bersama dalam kelompoknya definisi dari garis singgung lingkaran. Terlihat bahwa semua kelompok tidak mengalami kesulitan untuk menyimpulkan definisi dari garis singgung lingkaran. Berikut adalah contoh jawaban siswa.

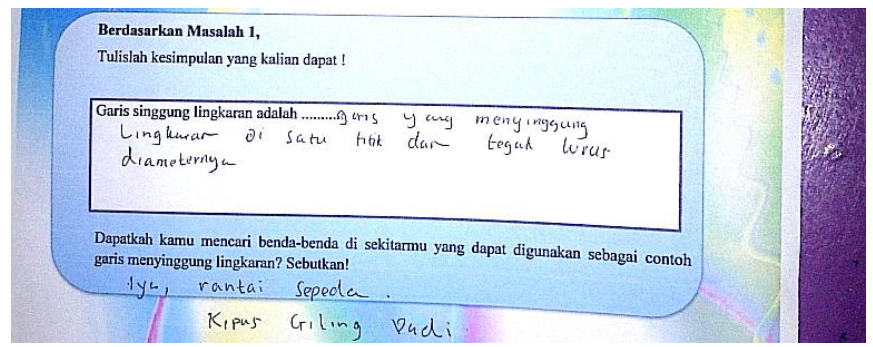

Gambar 9. Contoh kesimpulan siswa

Berdasarkan uraian jawaban-jawaban siswa pada uji coba bahan ajar, dapat disimpulkan tugas 1 sebagai salah satu tugas pada bahan ajar ini sudah dapat memfasilitasi siswa untuk menemukan defiisi garis singgung lingkaran. Meskipun dalam pelaksanaannya memang masih ditemukan ada siswa yang masih sangat kurang dalam menguasai materi prasyarat yang mendukung proses belajar mengajar seperti konsep garis yang sejajar dan sudut 
yang dibentuk oleh garis yang sejajar sehingga membutuhkan apersepsi dan scaffolding yang lebih dari guru.

\section{KESIMPULAN}

Berdasarkan hasil penelitian dan pembahasan dalam penelitian ini, dapat disimpulkan bahwa tugas 1 yang disajikan dalam bahan ajar dengan mempertimbangkan learning obstacle dan studi pendahuluan, mampu memfasilitasi siswa untuk mendefinisikan garis singgung lingkaran. Meskipun dalam pelaksanaannya memang masih ditemukan ada siswa yang masih kurang dalam menguasai materi prasyarat sehingga membutuhkan apersepsi dan scaffolding yang lebih dari guru.

Adapun tugas 2, tugas 3, dan tugas 4 yang disajikan dalam bahan ajar dengan mempertimbangkan learning obstacle dan studi pendahuluan mampu memfasilitasi siswa masing-masing untuk menurunkan rumus panjang garis singgung yang melalui satu titik di luar lingkaran, menurunkan rumus panjang garis singgung persekutuan dalam dua lingkaran, serta menurunkan rumus panjang garis singgung persekutuan luar dua lingkaran. Meskipun dalam proses mengerjakan LKS masih ditemukan siswa yang masih kurang memahami apa yang ditanyakan. Hal ini dapat diatasi dengan guru memberikan petunjuk yang membantu siswa tersebut.

\section{REKOMENDASI}

Berdasarkan hasil penelitian dan kesimpulan yang diperoleh, maka diajukan beberapa rekomendasi sebagai berikut.

1. Penelitian berikutnya diharapkan untuk melakukan eksperimen terhadap revisi bahan ajar di sekolah yang sama ataupun sekolah yang berbeda dengan tingkatan yang sama.

2. Terdapat beberapa tugas yang belum diselesaikan siswa karena kurangnya alokasi waktu yang tersedia. Jika akan melaksanakan eksperimen terhadap bahan ajar yang telah direvisi, direkomendasikan untuk menambah alokasi agar seluruh tugas-tugas dapat diselesaikan.

\section{UCAPAN TERIMAKASIH}

Dalam penyusunan penelitian ini tidak terlepas dari dukungan berbagai pihak. Peneliti mengucapkan terima kasih kepada Bapak Dr. Tatang Mulyana, M.Pd yang telah memberikan banyak masukan dalam pengembangan dan penyusunan penelitian ini. 


\section{REFERENSI}

Arikunto, S. (2010). Prosedur Penelitian: Suatu Pendekatan Praktik (Edisi Revisi). Jakarta: Rineka Cipta.

Brousseau, G. (1997). Theory of Didactical Situation in Mathematics. Dordrecht: Kluwer Academic Publishers.

Lidinillah, D. A. M. (tanpa tahun). Educational Design Research: a Theoretical Framework for Action. Tasikmalaya: Universitas Pendidikan Indonesia-Kampus Tasikmalaya.

Yudi, M., Ariani, N. M., \& Ramadianti, W. (2017). Desain Bahan Ajar Mata Kuliah Alajabar Linear untuk Mengembangkan Kemampuan Berfikir Kreatif Matematis. KALAMATIKA Jurnal Pendidikan Matematika, 2(1), 1-14.

Malalina, \& Kesumawati, N. (2013). Pengembangan Bahan Ajar Interaktif Berbasis Komputer Pokok Bahasan Lingkaran untuk Kelas VIII Sekolah Menengah Pertama. Jurnal Pendidikan Matematika, 7(2), 55-70.

Miles, M. B., \& Huberman, A. M. (1984). Qualitative data analysis: A sourcebook of new methods. In Qualitative data analysis: a sourcebook of new methods. Sage publications.

Moleong, J. (2010). Metodologi Penelitian Kualitatif. Bandung: PT Remaja Rosdakarya.

Mulyana, D. (2012). Metode Penelitian Kualitatif: Paradigma Baru Ilmu Komunikasi dan Ilmu Sosial Lainnya. Bandung: Remaja Rosdakarya.

Sholikhah, O. H., Budiyono, \& Saputro, D. R. S. (2014). Eksperimentasi Model Pembelajaran Kooperatif Tipe Group Investigation (GI) dan Numbered Heads Together (NHT) pada Materi Garis Singgung Lingkaran Ditinjau dari Kecerdasan Majemuk Siswa Kelas VIII SMP Negeri se-Kota Madiun Tahun Ajaran 2013/2014. Jurnal Elektronik Pembelajaran Matematika, 2(7), 727-739. 
Silver, E. A., et al. (1996). Posing Mathematical Problems: An Exploratory Study. Journal for Research in Mathematics Education, 27(3), 293-309.

Simon, M. A. (2014). Hypothetical Learning Trajectories in Mathematics Education. In Encyclopedia of Mathematics Education (pp. 272-275). Springer Netherlands.

Sugiyono. (2010). Metode Penelitian Kuantitatif Kualitatif dan R\&D. Bandung: Alfabeta.

Suherman, E. (1990). Petunjuk Praktis untuk Melaksanakan Evaluasi Pendidikan Matematika. Bandung: Wijayakusumah.

Slameto. (2010). Belajar dan Faktor-Faktor yang Mempengaruhinya. Jakarta: Rineka Cipta.

Steffe, L. P., \& D’Ambrosio, B. S. (1995). Toward a Working Model of Contructivist Teaching: A Reaction to Simon. Journal for Research in Mathematics Education, 26(2), 146-159.

Turmudi. (2010). Pembelajaran Matematika: Kini dan Kecenderungan Masa Mendatang. Bandung: FPMIPA UPI.

Yunus, M., Suyitno, H., \& Waluya, S. B. (2013). Pembelajaran TSTS Berbasis Kontruktivisme Berbantuan CD Pembelajaran untuk Menumbuhkan Kemampuan Komunikasi Matematis Siswa. Unnes Journal of Mathematics Education Research, 2(1), 164-169. 